
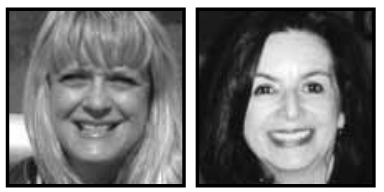

\title{
The Power of Imagination: Constructing Innovative Classrooms Through a Cultural-Historical Approach to Creative Education
}

\author{
M. Cathrene Connery, Ithaca College \\ Vera John-Steiner, University of New Mexico
}

\section{ABSTRACT}

All children have a need for and a right to educational programs that foster their creative ingenuity. This article presents a cultural-historical approach to creative education (CHACE) to cultivate K-5 students' higher order thinking, critical inquiries, and imaginative proficiencies. The text illustrates the application of Vygotskian theory in elementary, bilingual classrooms where interdisciplinary, collaborative, and apprentice initiatives in the arts, humanities, and sciences facilitate the acquisition of literacy, numeracy, and content knowledge. Relationship, affect, and cognitive pluralism are discussed as theoretical cornerstones in a system of activities to nurture children's novel interpretations, enhanced understandings, imaginative problem solving, critical innovations, and artistic creations within a supportive teaching-learning community.

\section{Introduction}

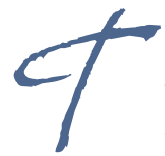

he world around us is constantly in flux, demanding adaptation to multifaceted environments. Our very existence depends on careful observation, creative imagination, innovative problem solving, and collaborative solution making. Creativity has been associated with a few solitary individuals "born" to accomplish great things; schools have isolated small percentages of children in "gifted and talented" programs. However, research reveals that joint problem solving, imagination, discipline, and precision are needed for all domains of human endeavor 
(Scribner, 1997). When, in children's lives, are such proficiencies developed? How and where do youth cultivate such complex psychological requisites? We assert that "the very nature of learning is creative" (Marjanovic-Shane, Connery, \& John-Steiner, 2010, p. 215) and that all children, especially linguistically, economically, and culturally diverse (LECD) students, have a right to educational programs that foster their creative ingenuity.

Across our careers, we have been privileged to witness the innovation of children and adults; these theoretical, research, and pedagogical journeys have provided resources for us to systematically apply cultural-historical theory into an educational approach that cultivates creativity. While primarily based on the writings of L.S. Vygotsky, our thinking is deeply influenced by the work of Maxine Greene, Eliot Eisner, Kieran Egan, Natalia Gajdamaschko, Gunter Kress, Shirley Brice Heath, and members of the Cultural-historical Activity Theory electronic community. In this article, we offer readers a cultural-historical approach to creative education (CHACE) derived from our scholarly study of the mind and work in K-5th grade content English as a Second Language and bilingual classrooms in the western United States.

\section{Vygotsky's Theoretical and Methodological Framework}

Scholars have long debated the nature of creativity without agreeing on a common definition. Vygotsky characterizes creativity as "a transformative activity where emotion, meaning, and cognitive symbols are synthesized" (John-Steiner et al., 2010, p. 12). His cultural-historical framework includes everyday problem solving and creative artifacts capable of producing a lasting, generational impact. Because he ascertains, "Creativity exists not only where it creates great historical works, but also everywhere human imagination combines, changes, and creates anything new," (Vygotsky as quoted in Smolucha, 1992, p. 53) the efforts of teachers and students are defined as imaginative, innovative, and collaborative endeavors (Egan, 2006; Gajdamaschko, 2005). 


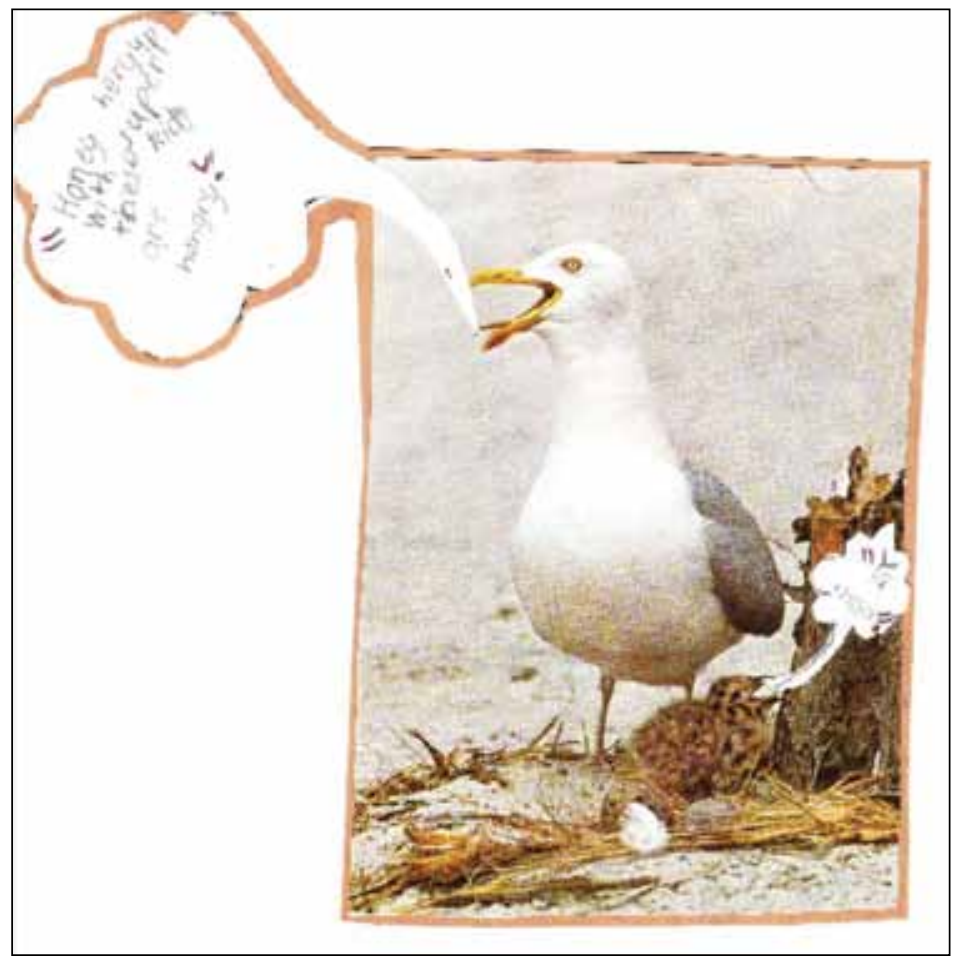

Fig. 1: Claire's punctuation cartoon (courtesy of the artist)

In building on Vygotsky's framework, we propose that creative education is the mindful, intentional nurturing of a system of activities resulting in novel interpretations, enhanced understandings, imaginative problem solving, critical innovations, and artistic creations achieved with the support of a community of learners and teachers. The goal of a cultural-historical approach to creative education (CHACE) is to develop children's capacity for higher order thinking, including critical and creative proficiencies associated with inquiry, problem solving, and pragmatic applications in the arts, humanities, and sciences. The aims of CHACE are not at odds with the traditional curriculum, nor the implementation of stand-alone, art curriculums. We propose, instead, an integrated approach that develops the power of imagination. In CHACE classrooms, first graders might learn to correctly apply quotation marks in Language Arts by writing cartoons like the example in Figure 1 where a father seagull exclaims, "Honey, hurry up with supper! These kids are hungry!" Alternatively, fifth graders might film documentaries integrating information from Social Studies, Science, and Mathematics. What is different about CHACE is that higher order thinking is the origin, focus, and product of the curriculum. 


\section{Obuchenie: Teaching-Learning as a Connected Relationship}

CHACE redefines teaching and learning as complementary, collaborative, and relational processes. This principle provides educators with a theoretical blueprint to direct their choices, communications, and actions including assessments undertaken at the start of each school year. When identifying students' academic challenges in relationship to grade-level performance standards, these diagnostic tools have the potential of reinforcing remedial, polarizing relationships between teachers and students. When correctly utilized to collect relevant information, such measures can reveal what knowledge or proficiencies students need to develop. Teachers can then use this data to strategize and construct individualized, small group, and class instructional plans.

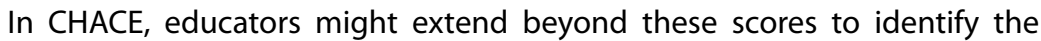
unique funds of knowledge, talents, and interests of their students, families, and communities (Moll, 1990). Imagine the teacher who challenges her elementary students on the first day of school asking, "Which one of you will find a cure for cancer? Who will write a poem that will be read at a presidential inauguration? Win an Olympic gold medal? Play, dance, or act before heads of state? Exhibit at the Smithsonian? Take a photo that changes the view of the world? Devise an invention that helps people and the environment at the same time? This year, we are going to work together to get you closer to realizing these dreams."

Toward this end, CHACE practitioners renegotiate the power relationships that often divide or isolate teachers and students. Educators should not abandon their professional knowledge, adult roles, or seriousness of purpose; rather, the work of teachers and their students is recast in relational terms, replacing one-way, authoritarian banking approaches to education (Freire, 1970) with Vygotsky's obuchenie (1933d). The concept of obuchenie represents teaching and learning as connected, complementary forms of meaning making where teachers act "first among learners" (Miyazaki, 2007). In innovative classrooms, teachers verbally walk students through steps to collectively solve mathematical problems. They can challenge students to identify ways healthy adults resolve social issues, hurt feelings, or come to agreements. Innovative teachers can also model self-protection, self-soothing, and resilient behaviors. They might engage in "think alouds" when reading picture books or novels to the class, verbally illustrating what images come to mind as they interact with texts as expert readers.

In applying these principles, teachers infuse the teaching/learning process with creative insights and solutions. A major assumption in Vygotsky's writings is that creative work is profoundly social as well as individual: 
Art is the social within us, and even if its action is performed by a single individual it does not mean that its essence is individual... Art is the social technique of emotion, a tool of society which brings the most intimate and personal aspects of our being into the circle of social life. (1971, p. 249)

This principle has been demonstrated by many children with whom we have worked in the language-literacy arts. In one instance, a fourth-grader, whose father had been accidentally killed, composed a short story about a Diné boy named Little Three Wounds during the Long Walk to Bosque Redondo. The student had confided earlier in the school year that while he had witnessed his father's death as a kindergartener, he did not have any clear memory of the incident and did not like to speak about it. However, the child's narrative reflected specific aspects of the actual tragedy and his feelings about his father's passing. The account combined historical facts about the forced march, the starvation of the imprisoned Navajo, and the child's developmental interests. Amid horse-chasing, hunting, and scenes of family life, Little Three Wounds' family is captured and forced to leave its ancestral lands. At the climax of the story, the protagonist's father is murdered by a U.S. soldier. The child wrote:

The sun beat down on the tall limestone figures that towered over the heads of the throng traveling through the desolate valley. The soldiers had decided to abandon a baby whose crying pierced the ears of the slowly moving cluster. Little Three Wounds' father, in shackles, stopped and said in a serious voice, "I will not go any further away from my home." His Pawnee interpreter told the lieutenant what Yellow Bear had said. The soldier was absolutely furious! The interpreter told Yellow Bear to go on or be killed at the soldiers bidding. Little Three Wounds father remained still with a look of hate on his face.

The lieutenant drew his midnight black and brown rifle from its holster on the side of the supply wagon. He raised the gun to his eye. Little Three Wounds was watching with horror, standing still so frightened. The lieutenant pulled his index finger back. Little Three Wounds covered his face with his hands. The shot whistled through the air for what seemed like eternity to the young brave. His father dropped to the ground.

After a series of conflicts, the student composed a fictitious ending where Little Three Wounds leads his people to safety and food. While historically inaccurate, the child's conclusion combines elements of the Nez Perce flight into Canada that had also been studied by the class as well as the child's own catharsis and reconnection with his mother, concluding the narrative with a powerful, imaginative sentence: 
The Navajos traveled through thick and thin on their journey. It was a very long trip, and a hard one, too. Their travels took them fourteen days with the white soldiers about five miles behind them all the way. But, thanks to Little Three Wounds, the white men never caught up.

When they crossed the border of Canada, everybody cheered and hugged Little Three Wounds. His mother kissed the amazing eleven year old boy. His tribe gave him a new name: "He Who Saved His People". The young brave took his father's turquoise necklace and held it tightly in his hand. (Courtesy of the Writer \& His Mother)

After reading the story to his classmates, a profound silence fell across the classroom; the fourth graders regarded their classmate with new eyes. A discussion ensued regarding loss and resilience, with a multiplicity of examples offered from the children's lives. Our conversation concluded by listing examples of artists and scientists who had additionally experienced great tragedy in their young lives and who had gone on to contribute to humankind.

\section{Learning and Development Inside the ZPD}

In a CHACE classroom, educators intentionally cultivate multiple collaborations between learners and thinkers by consciously connecting novice and expert learners in a host of meaning-making partnerships. Just as the painter selects and mixes colors in the service of illustrating knowledge, so the creative teacher knowingly combines individuals of a variety of ages, proficiencies, and learning styles to enhance learning. These carefully conceived collaborations link children to essential social sources, facilitating the measured appropriation of knowledge, skills, strategies, and dispositions.

In innovative classrooms, teachers might validate, recruit, and extend children's funds of knowledge and academic strengths by assigning "consulting positions" that share student expertise with the larger class. Children in the CHACE classroom can exercise their own agency when referring to a list of peer-writing consultants to help them brainstorm names for a character, indent paragraphs, conjugate the correct tense of a verb, or select a juicy adjective from the thesaurus. A quick peek into an innovative classroom might confirm the presence of parents and community partners engaged in discussions with learners, sharing their expertise and cultural knowledge. 
These instructional collaborations form the very structures of the zone of proximal development (ZPD) necessary for learning to take place. Vygotsky (1978) described the ZPD as "the distance between the actual developmental level as determined by independent problem-solving and the level of potential development as determined through problem-solving under adult guidance or in collaboration with more capable peers" (p. 86). Within the ZPD, learners and partners engage in two-way interactions and collective meaning making, "transcend[ing] the constraints of biology, of time, of habit and achieve a fuller self, beyond the limitations and the talents of the isolated individual" (John-Steiner, 2000, pp. 187-188).

The CHACE approach taps teachers' professional expertise in order to cultivate joint productive attention, nurture shared and distributed meanings through carefully constructed ZPDs, and implement open-ended or goal-directed activities, role-play, and discussions. It values the application of educators' sophisticated set of relational resources and social skills including Rychly's (2012) definition of receptive discourse where teachers employ understandings and strategies related to the dual directionality of language as a distinct form of classroom discourse facilitating student agency, learning, and language acquisition.

CHACE educators make cultural information, academic strategies, and linguistic problem-solving concrete, accessible, and explicit. Real-world analogies can help children make sense of the English language. For example, when asked if they always follow directions, most primary students will say that their home and school behaviors differ. When metaphorically extended to abstract orthographic patterns (the "ea" "bead" or "ph" or /f/ sound in "phone"), children understand that letters, like themselves, don't always follow "the rules."

It is essential that teachers highlight social sources and constructs that might be otherwise invisible or unattainable to children and their communities. These resources are often right in front of us as the following account illustrates:

It was a beautiful, sunny spring day in a Northern New Mexico Pueblo. These are traditional villages next to the Rio Grande river. The Pueblo school was known for its engaged teachers and eager students. This day was a little noisy because there was construction going on outside the second-grade class window. Most of the workmen, being members of the Navajo nation, were taller than the Pueblo natives. The children would have liked to speak to them, but their Tewa language was quite different from the Navajo language their guests spoke. 
Some of the younger men brought their wives for the weeks they were working in the Pueblo, and one young woman looked a little sad while watching the construction. The children had noticed that she sometimes worked on a loom with different colored threads. They suggested to their teacher that they should invite her into the classroom with her loom; perhaps they could exchange a few words in English. And so they did.

The young wife came several times, and showed them how she combined colors, following a design that she envisioned in her mind. One day, she brought some natural dye, and deepened the color of one of her threads. The teacher brought in books about the famous Navajo rugs and their varied, frequently geometric designs. The students wanted to know more about diverse Indian tribes-some of them their neighbors, others living far away-about their past, and what they shared as Native people. ${ }^{1}$

\section{Classrooms as Sites and Sources for Learning}

Teachers engaged in CHACE consciously consider and construct all aspects of the learning environment including the physical arrangement of the classroom, schedules, protocols, and routines. One of our colleagues gift-wraps the drawers and cabinets of her classroom in early August. During the first week of school, her students unwrap these gifts and discuss how they will use their resources or spaces. This activity reflects that learning environments serve as both the site and source of learning. Vygotsky's (1981) genetic law of cultural development notes that the knowledge, skills strategies, and dispositions teachers seek to cultivate "appear twice or on two planes. First [they] appear on the social plane and then it appears on the psychological plane. First it appears between people as an interpsychological category and then within the individual child as an intrapsychological category" (p. 163). In order for a particular understanding to fully develop, the mature form must be evidenced or utilized in the innovative classroom.

In the CHACE classroom, furniture, supplies, and other items are labeled with icons sporting children's languages as supports for their biliterate proficiencies. In innovative environments, children might collectively brainstorm a list of classroom jobs to promote the smooth functioning of their community. After deliberating a minimum wage, a student personnel director can work with the class human resources manager to hire specific positions, monitor performance, and advertise new jobs dictated by classroom needs (see Fig. 2). A student veterinarian might take responsibility for the care of a pet, receiving a weekly paycheck from the class bank 
for her efforts. Children can then spend their earnings at a Friday auction where recycled toys, books, and other items are bid on in the children's dual languages.
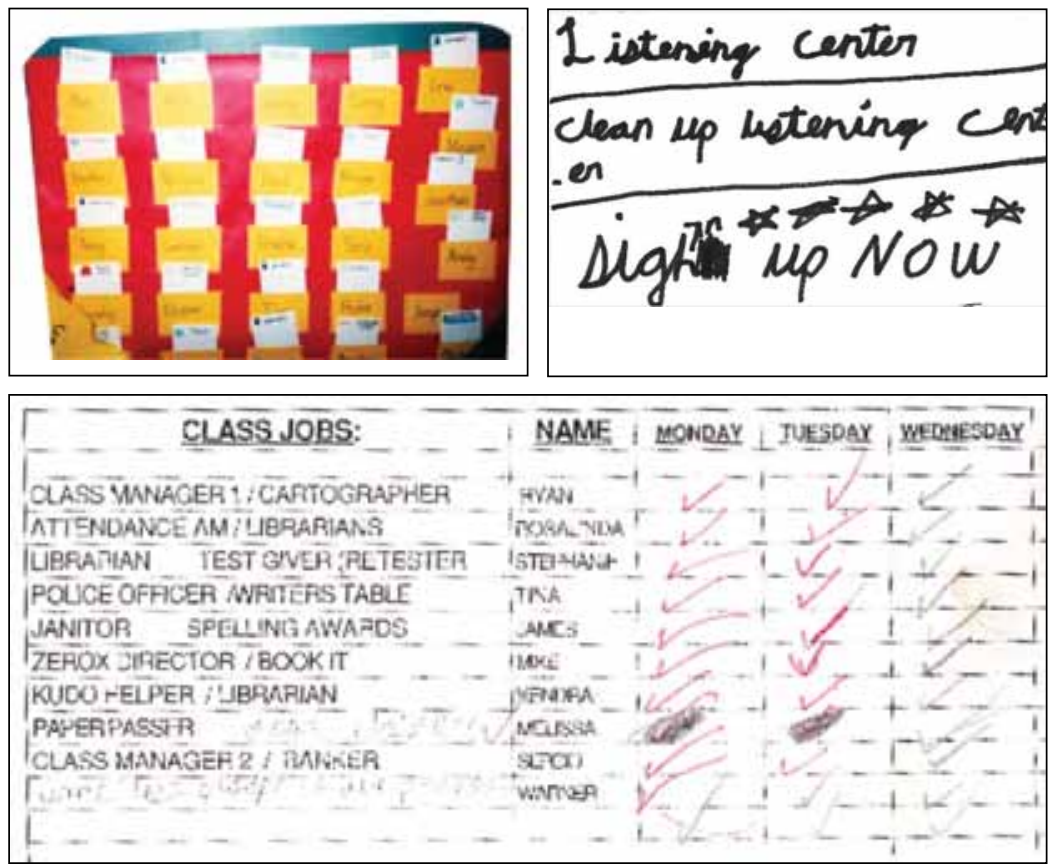

Fig. 2: Job board, announcement, and checklist

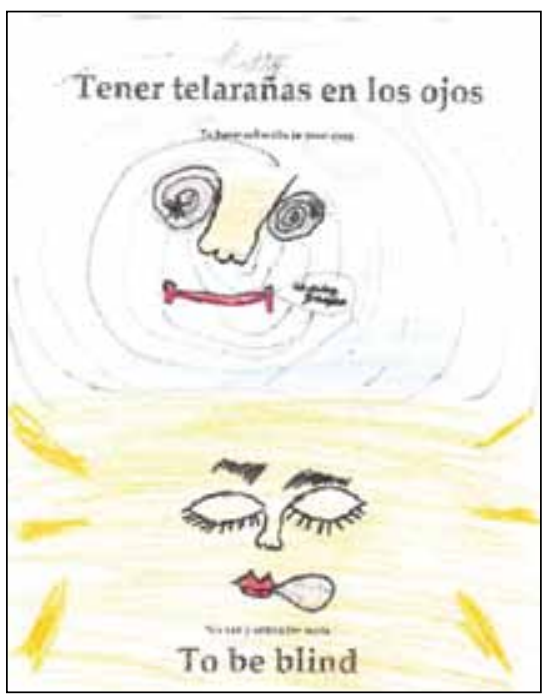

Fig. 3: Dual language idiom posters 
In the innovative classroom, multilingual dyads might illustrate cultural idioms; children's linguistic and communal knowledge can be recorded on posters that are shared weekly across the course of the academic year (see Fig. 3). On Mondays, children might enter a new bilingual idiom into their personal language dictionaries. Both teacher and students can anticipate interactions, situations, and events across the week when they can appropriately apply an adopted idiom or dicho.

\section{The Resource and Role of Affect}

Such deliberate construction of the learning environment recognizes the role of affect as an essential resource in learning established by neuroscientists including Antonio Damasio (2000, 2005). Connery (2011) has written about the "emotional curriculum" interwoven with cognitive objectives "derived from the lived experience of children; their construction of identity in their private and public lives; the response, meaning, and affection they assign to teachers, classmates, and school; and both their individual and collective feelings of agency" (p. 47). In CHACE, the emotional curriculum is made manifest by strategically developing children's positive sense of self-worth and resilience required for repeated risk-taking in the learning process.

Practitioners can deliberately tap children's enthusiasm to fuel excitement for the learning process by actively soliciting what the children would like to learn. These interests can be recorded with suggestions offered by parents and caregivers to incorporate cultural knowledge, multicultural-biliterate proficiencies, and critical perspectives often absent in educational canon. After constructing a curriculum map, educators might share a tentative schedule of when and how the class might integrate state standards, district initiatives, and grade-level curriculum with these topics. We recall that a fourth grader's excitement at the prospect of studying the Great Barrier Reef sustained his engagement across the course of two academic quarters.

Conversely, teachers can also sensitively contextualize the sorrows and struggles children bring to school through their informal play, casual interactions, academic discussions, and formal assignments. It is not only common, but also healthy for students to draw and write about personal tragedies in the writing process. Teachers can utilize narratives about the passing of a pet or another loss to promote positive self-care and the development of wisdom. When provided with safety and respect, children make profound, transformative connections with teachers, classmates, and the curriculum. We are reminded of a discussion on the Underground Railroad with fifth graders which began in an uncharacteristically quiet manner. After 
prompting the silent students with a few open-ended questions, a child timidly raised her hand and offered, "But maestra (teacher), weren't they a lot like us?"

The student was identifying with the conditions of African-Americans who sought freedom from slavery in the 1800 s by escaping to the North with her family and classmates' histories as the children of undocumented Mexican laborers. In our subsequent discussion, the children related their own personal hardships, including leaving valued family members, toys, pets, and places behind. They drew parallels with the African-American experience of having to wrap their own feet in rags after the terrain destroyed their shoes. Our discussion encompassed the historical similarities and differences of both groups of people, including geographic boundaries, socioeconomic motivations, and religious and political perspectives. Perhaps the best learning outcome of our session occurred when the children discovered that civil rights law protected them from being illegally removed from school by the Office of Immigration and Naturalization Services (INS).

Creative teachers seek to understand the role of affect in developing imagination (Gajdamaschko, 2005). Vygotsky suggests "the internal logic of feeling will represent the most subjective, most internal form of imagination" (1930/2004, p. 19). Just as emotion impacts imagination, imagination also shapes emotion.

[This is why] works of art created by their author's imaginations can have such a strong emotional effect on us. The passions and fates of imaginary characters, their joys and sorrows move, disturb, and excite us, despite the fact that we know these are not real events, but rather the products of fantasy. This occurs only because the emotions that take hold of us from the artistic images on the pages of books or from the stage are completely real, and we experience them truly, seriously, and deeply. (p. 20)

Such imaginative experience is often memorable for young children. The emotional aspect of creative engagement often facilitates greater understandings and connections to the curriculum; secondary educators, including Smagorinsky (2010) and Zoss (2010), document this process.

\section{The Playful Curriculum as Imaginative Invitation}

CHACE is also distinguished by the development of analytical, expressive, and innovative thought including learners' common and unique abilities related to cognitive pluralism, multiculturalism, and bilingual-biliterate proficiencies. These 
objectives are realized when teachers and students forge connections across content areas in spaces where open-ended discoveries and playful adventures are interwoven into the fabric of the targeted curriculum.

Developmentally, children's play is the beginning of discovery and the construction of novelty. Vygotsky (1993/1976) describes play as an interactive form of embodied imagination. Both Goncu (2012) and Holzman (2010) assert that children construct their relationships to themselves, other individuals, social groups, and the material world through play. Marjanovic-Shane (2010) highlights the relational, emotional, and transformative nature of play as a means by which stress, fears, and aspirations have the potential to evolve into collective meanings through playful activity. St. John's (2010) accounts of young children's free play with musical instruments echo these findings while highlighting Vygotsky's contention that "imagination operates not freely, but directed by someone else's experience, as if according to someone else's instructions" (1930/2004, p. 17).

While play has been emphasized as part of creativity by many psychologists who have recently focused on this topic, Vygotsky's (1930/2004) approach displays his broader view of seeing higher psychological processes as interrelated, psychological or "complex functional systems." The construction of these dynamic systems requires what Pelaprat and Cole (2011) have named "gap filling" from the Russian term "voobrazhenie" translated as "moving into image making." They suggest that imagination is an ever-present part of human thought

and should neither be understood as a special ability nor as the creation of 'unreal' fantasies... There are fundamental 'gaps' that must be resolved for individuals to think or act in relation to the world. Resolving these gaps through image making constitutes the self and the world in the same process. It is the human form of cognition. (p. 413)

Further, Vygotsky (1934/1987) argues strongly that the development of speech is a powerful impetus for the development of imagination. While fantasy is connected to the visual richness of dreams, language further broadens the child's imagination by presenting the not here, the not now, the not real. He contends, "The child can express in words something that does not coincide with the precise arrangement of objects or representations. This provides him the power to move with extraordinary freedom in the sphere of impressions, designating them with words" (p. 346). 
In the larger literature on creative classrooms, the focus lies on the individual teacher or student. However, in CHACE, practitioners can adopt a culturally relevant, curricular framework to systematically and imaginatively scaffold learning experiences for their entire class. For example, at the start of the school year when teaching in separate fourth and fifth grade Dual Immersion classrooms, we adopted the metaphor of learning as an adventurous journey. The language-literacy arts were presented as the vehicle by which the children might realize their dreams. A design competition was held for students to propose what a class aircraft might look like; the children worked as individuals, pairs, or in small groups to illustrate their conception of a Flying Literature Mobile (FLM) (see Fig. 4).

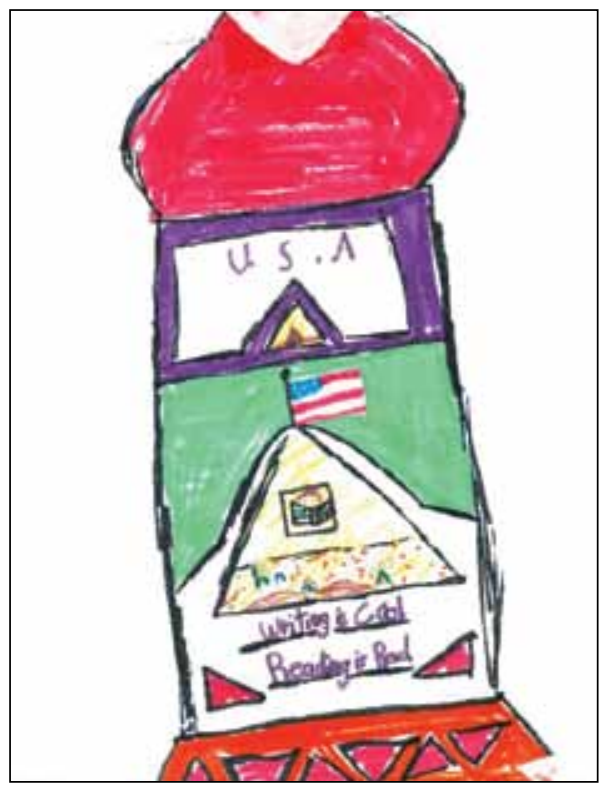

Fig. 4: Design proposal for Flying Literature Mobile (FLM)

After a class vote to select the best design, the artist and teacher constructed the rocket out of butcher paper, boxes, construction paper, and found objects each student brought to adhere to the imaginative vehicle (see Fig. 5). Parents attended a "Back to School Night," only to discover that their children would appropriate, apply, and refine an integrated, grade-level curriculum, while floating around the cosmos, wandering back in time, exploring exotic locations, and solve critical problems in the Flying Literature Mobile (FLM). 


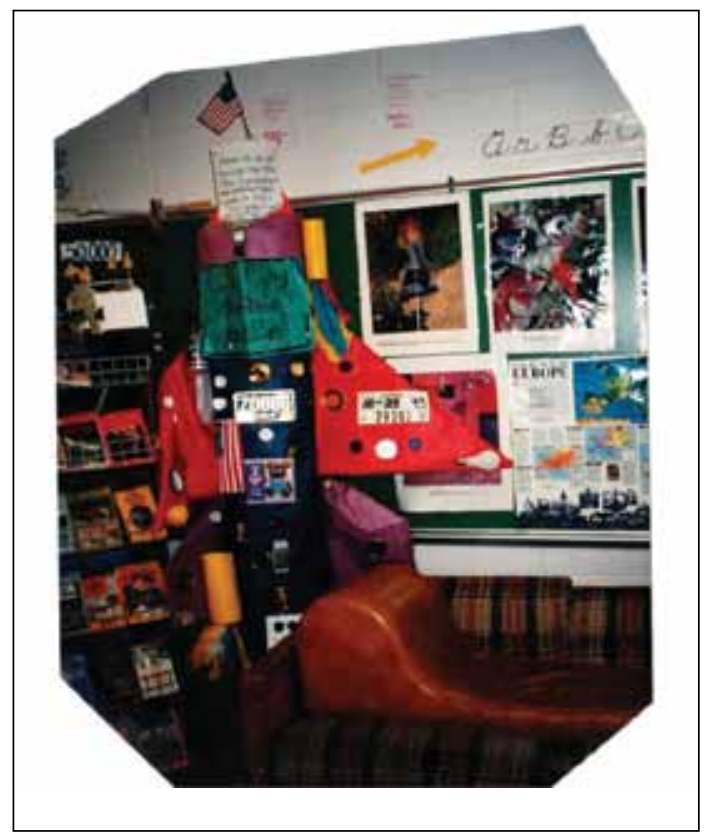

Fig. 5: Flying Literature Mobile (FLM)

A daily class narrative was constructed around these adventures. Each morning, students pounded on the door to read informative communications from the FLM's control center that alluded to, challenged, or targeted specific literacy, numeracy, and content knowledge, skills, strategies, and dispositions. The example in Figure 6 foreshadows the study and application of geographical concepts of latitude and longitudinal lines.

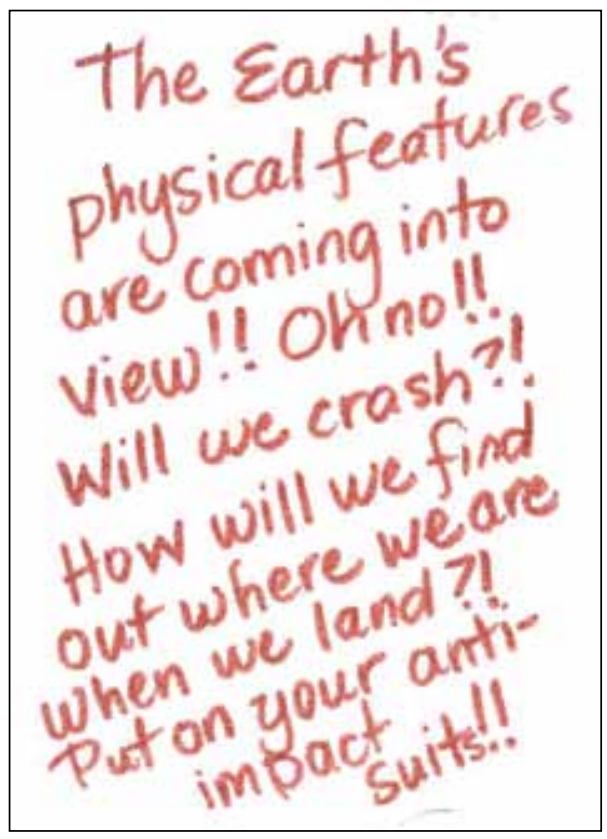

Fig. 6: FLM control center communication sample 
Other innovative teachers might frame their curriculum by challenging their classes to agree on an essential question as a curricular prism for student inquiry across the year. Teachers and children have examined topics such as, "What makes a person courageous?" or, "What is justice?" After much spirited debate, one of our fifth grade classes adopted the guiding query, "Who have we been, who are we now, and who will we be in the future?" In the fall, students wrote themselves letters addressing the first two components of the inquiry. These epistles were hidden away in miniature "time capsules" with personal commercials or student videos filmed during the first month of school. At the holidays, students revisited the essential question while evaluating personal progress on individual goals; these statements were then added to the time capsules. In June, the children "liberated" the information in the capsules to assist them in evaluating the literacy proficiencies and work samples they had collected in portfolios throughout the year. In contrast to traditional forms of assessment, the essential question provided both an individual and collective lens for children to assign meanings to their growth.

\section{Cultivating Competence and Cognitive Pluralism}

We experience life through all our senses, communicating our impressions through symbol systems. In Vygotsky's theory, language plays a primary role by which experience is both deepened and transformed. However, he recognized that our semiotic means include visual systems (traffic lights and sign language), kinesthetic icons (the Olympic torch), musical notation, the multimodal performing arts, mathematical symbols and scientific reasoning. Sustained exposure to any one of these meaning-making activities requires curiosity and immersion. CHACE provides children with the opportunity to transact with, imitate, and develop multi-modal means. These competencies call upon combinations of Gardner's (1983) multiple intelligences, including intrapersonal understanding through the exploration of the learner's shifting strengths and weaknesses when collaborating in the classroom, studio, laboratory, and life.

CHACE recognizes that the role of culturally patterned activities influences the availability and salience of a particular modality. For example, John-Steiner's (1984) investigation of the impact of Native Southwestern crafts upon Pueblo children's learning styles found that the children relied on observational learning and possessed highly developed visual skills in contrast to their urban peers. She (1995) refers to these effects of culture as cognitive pluralism, noting that the cross-cultural encounters of Native students and non-indigenous teachers can be either a source of tension or synthesis of modalities and cultures. 
Innovative teachers can construct imaginative connections between themselves, their students, and the curriculum by honoring and employing students' cognitive pluralism. For instance, third graders might precisely label the parts of a flower on a giant chart in their native or second language only to act out the respective structural functions in a dance to Aaron Copeland's "Flight of the Bumblebee" (see Fig. 7).

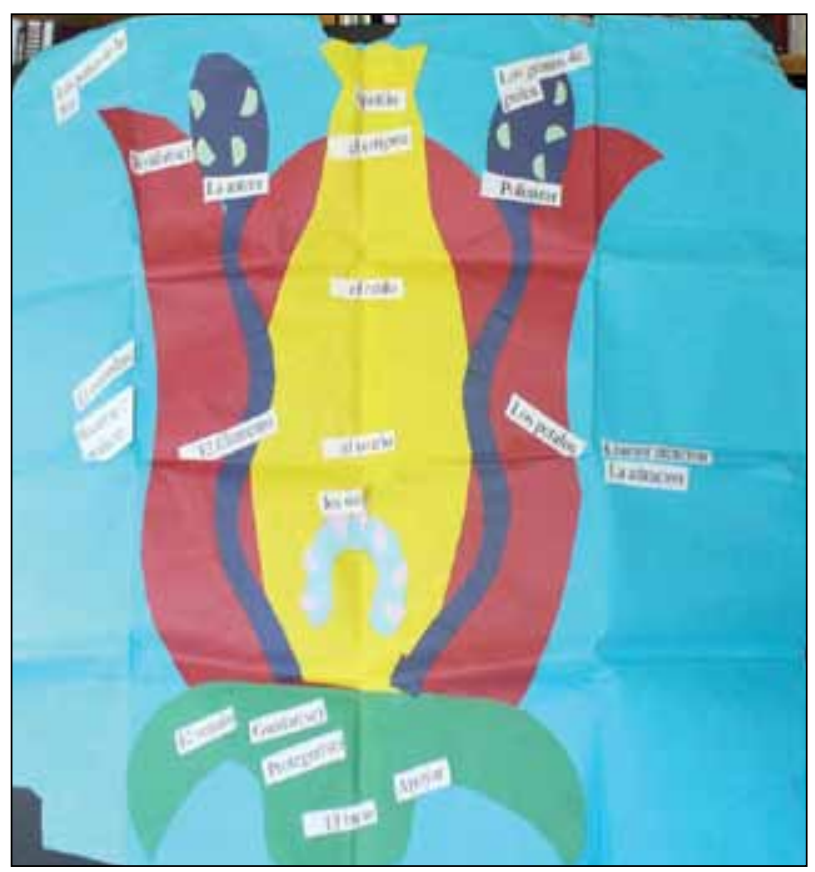

Fig. 7: La Tablas de las partes de la flor / Parts of the flower chart

The entire range of psychological tools, from language, musical notes, mathematical formulas, and other mediating means offered through the arts and technology can be made available to learners. In $\mathrm{CHACE}$, teachers might mediate and co-construct complex information using virtual field trips to the Smithsonian's Egyptian collection, edible ingredients to represent the parts of a cell, or employ video clips highlighting underwater volcanic eruptions. PowerPoint software, like the book commercial created as a preview for Kathleen Krull's (2003) text, Harvesting Hope (accessed by clicking here: http://www.learnquebec.ca/learninglandscapes/documents/Harvest ing_Hope.pdf), enriches children's prior knowledge while prompting a host of predictions about the text. Conversely, children might internalize, record, and express higher order thinking, academic proficiencies, or content knowledge through a multiplicity of learning formats including song, debate, games, experimentation, art making, and dance. The illustrated verses of a song about seed dispersal, found in Figure 8 , can assist student memory and recall. 
The Power of Imagination: Constructing Innovative Classrooms Through a Cultural-Historical Approach to Creative Education

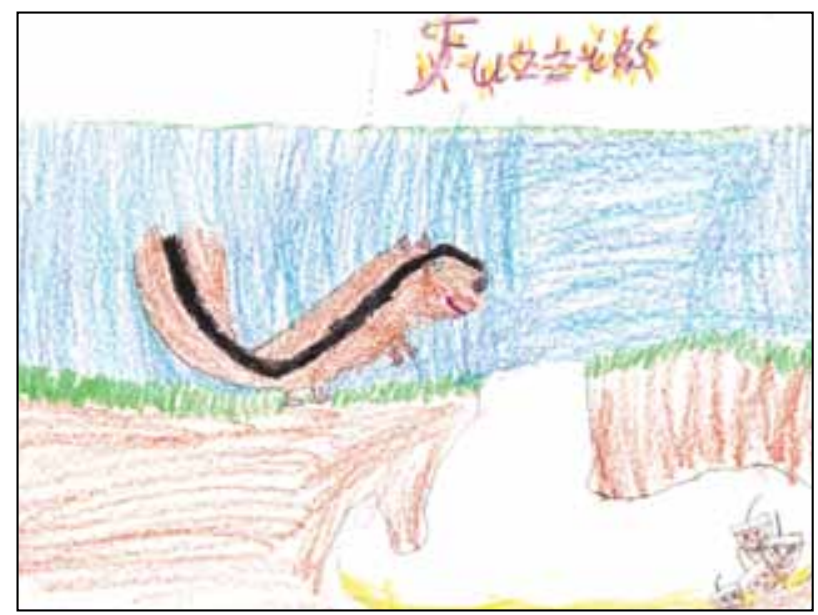

Fig. 8: Seed dispersal drawing - fuzzies

Similarly, the chronological segments of a book mobile can be used to relate specific periods in the biography of important historical figures like Frederick Douglas (see Fig. 9).

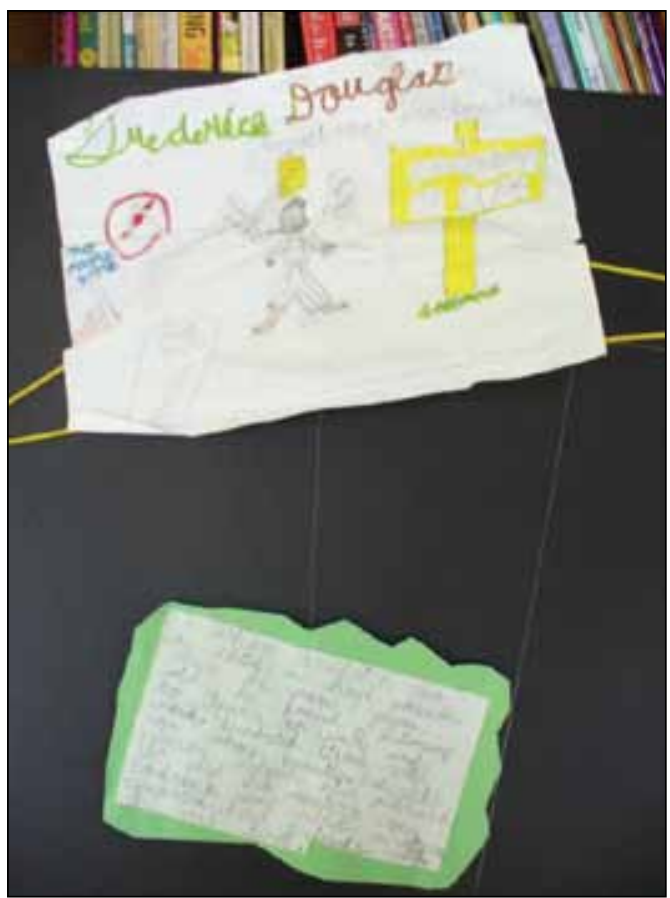

Fig. 9: Frederick Douglas biography book mobile 
Artifacts that draw on increasingly sophisticated forms of cognition including application, analysis, evaluation, and synthesis (Anderson \& Krathwohl et al., 2000) can be constructed by combining and applying content and genres to spotlight essential, critical, or creative aspects of the curriculum. It is one thing for students to write an outline of the historical conflict between British and American Colonists from their Social Studies text; Vygotsky (1930/2004) describes such as reproductive activity. However, asking children to compose and justify a recipe, rap, or re-enactment of the American Revolution initiates a creative recombination of knowledge, skills, strategies, and dispositions. Challenging fourth graders to write an invitation to a birthday party for each of the planets in the solar system (see Fig. 10) entails reproductive as well as creative thinking, whereby knowledge regarding planetary composition, climate, rotations vs. revolutions is called on in combination with literacy processes to "rework[s] elements ......and use[s] them to generate new propositions and new behavior" (Vygotsky, 1930/2004, p. 9).

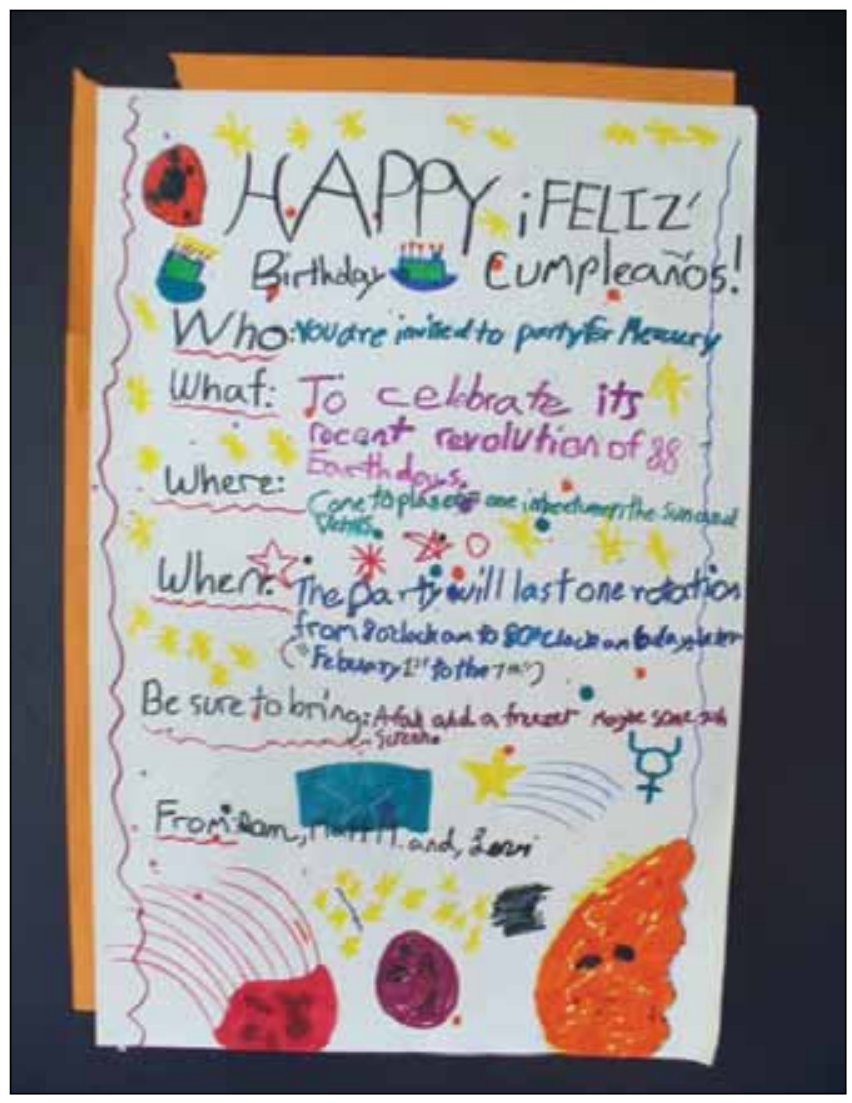

Fig. 10: Birthday invitation for the planet Mercury 


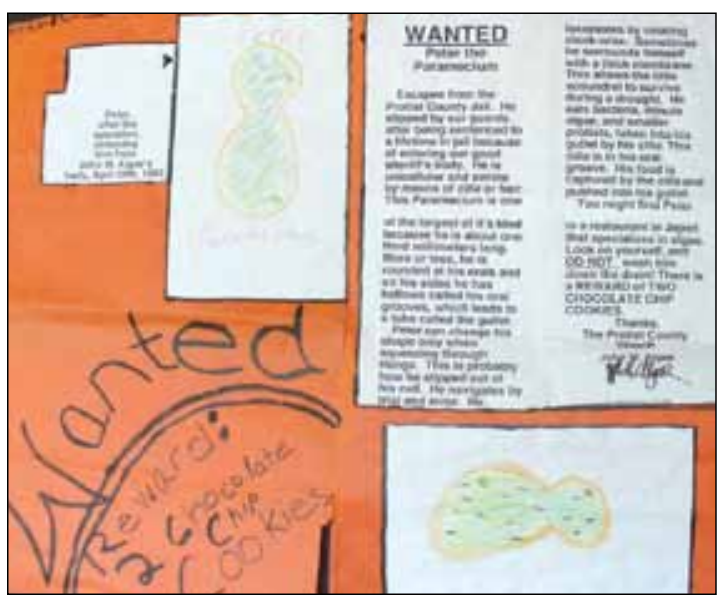

Fig. 11: Wanted poster for Peter the paramecium

Once children are invited to engage in these imaginative ventures, they will construct their own innovative artifacts to reflect curricular knowledge and competencies. Figure 11 displays a wanted poster for Peter the Paramecium composed by two fifth graders after reading about unicellular protozoa in their science text. The artifact includes two mug shots, a detailed description of the criminal, grounds for his arrest, and a reward for his capture, written and fictitiously signed by the Protist County Sheriff. With the exception of identifying general grading criteria with their teacher, the entire project was devised by the two girls.

\section{An Apprentice Approach to Content Development}

Vygotsky once noted, "It is precisely human creative activity that makes the human being a creature oriented toward the future, creating the future and thus altering his own present" (1930/2004, p. 9). This premise is especially true for young children in their attempts to appropriate and recreate cultural tools from the preceding generation (Cole, 1996). CHACE builds on Vygotsky's view of students as "active, vigorous participants in their own existence and ... at each stage of development, children acquire the means by which they can completely affect their world and themselves" (John-Steiner \& Souberman, 1978, p. 123). The implementation of an apprentice approach further cultivates the power of imagination through fieldwork simulations and social justice projects. 
Field apprenticeships provide educators with an alternative venue to construct teaching-learning spaces where children engage in open-ended discoveries and applied adventures. These imaginative ZPDs, like the paleontological study of a second grade class highlighted in Figures 12-14, can integrate the entire curriculum. After entering a class time machine, hiking around the swamps of the Triassic, Jurassic, and Cretaceous periods, and composing an $A B C$ book of the dinosaurs students met in role-play, teachers might bury bones they have saved in a large dirt pile on school grounds. The next morning, the children then convene into scientific teams after being assigned specific roles to engage in a paleontological dig. The students can apply the curriculum acquired across the disciplines to stake a claim, describe their field area, extract specimens, and record critical attributes of their findings. A serious focus can be placed on the proper application of procedures including the use of map coordinates, empirical observation, the metric system, and disciplinespecific writing genres. Through the scientific method, the children can playfully explore authentic physical and psychological tools used by professionals, transforming everyday knowledge into scientific understandings (Vygotsky, 1934/1987). After the discovery of specimens in the field (Fig. 12), students might prepare and transport artifacts to a classroom laboratory (Fig. 13) where their findings undergo additional examination, scientific notation, and preservative treatments in new scientific teams. By the end of the unit, the children can design, build, and curate an exhibition for a class museum (Fig. 14). The exhibit might be advertised in school hallways, attended by younger children who receive invitations from siblings or older peers. The final display can be shared with the larger community through a class newsletter or museum catalogue recording the event.

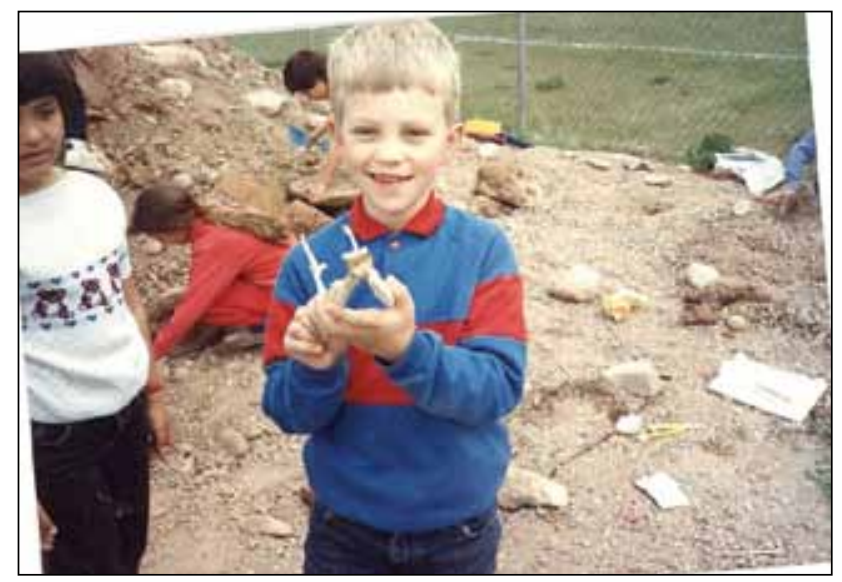

Fig. 12: Specimen discovery at paleontological expedition (courtesy of the students and their families) 
The Power of Imagination: Constructing Innovative Classrooms Through a Cultural-Historical Approach to Creative Education

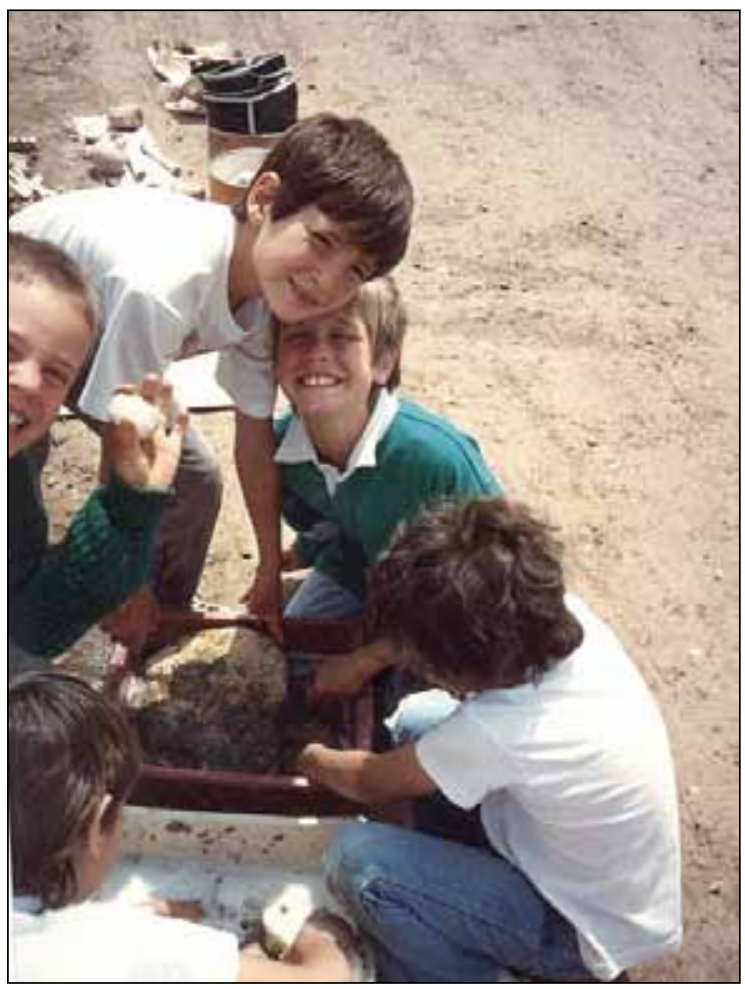

Fig. 13: Preparation of artifacts for transportation to the lab (courtesy of the students and their families)

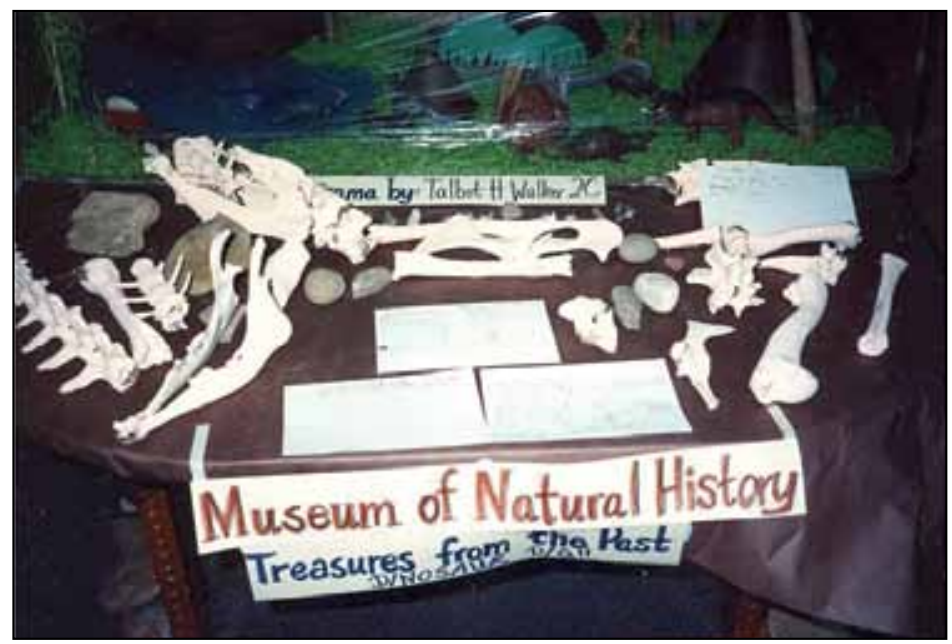

Fig. 14: Museum exhibition of paleontological findings 
Finally, CHACE classrooms extend Vygotsky's notion that emotion fuels all human endeavors including scientific discovery, sports, and work for the welfare of others. Social justice projects can similarly provide motivating projects where children appropriate and refine knowledge, skills, strategies, and dispositions while becoming agents of change. For example, our second graders collected a sufficient number of aluminum cans to purchase an acre of rain forest for protection by a conservation group. Fourth graders completed an investigation on nutrition, food, and hunger by sponsoring a school-wide, canned food drive called the Great Donation Estimation Challenge, showcasing their proficiencies in the use of graphs, multiplication, and percentages (see Fig. 15 and Fig. 16). Fifth-grade emergent biliterates decided the best way they could combat youth drug use was to donate Spanish-English recordings of their favorite pieces of children's literature for check-out at the local library. By targeting constructive solutions, children can actualize the old axiom that "knowledge is power." In realizing their dreams, students learn to locate themselves and others in positions of empowerment.

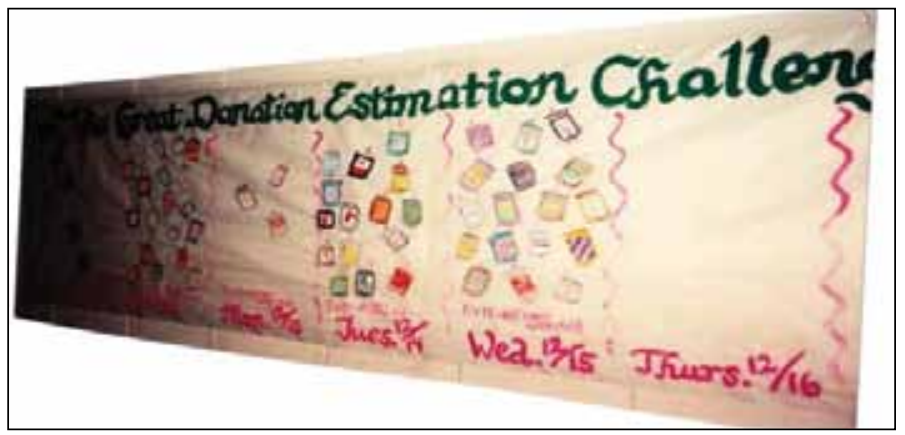

Fig. 15: The great donation estimation challenge graph

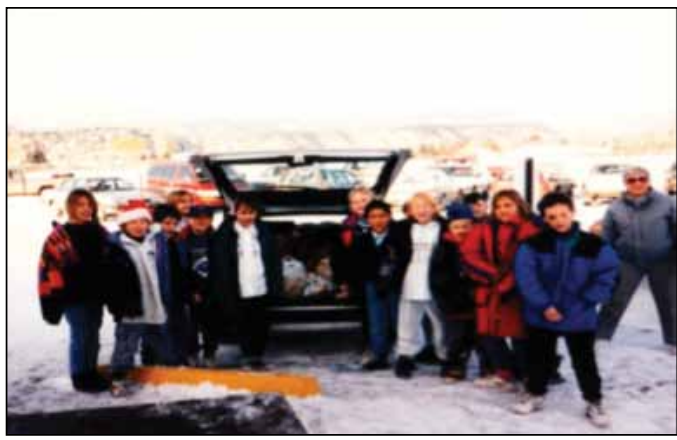

Fig. 16: The great donation estimation challenge canned food delivery

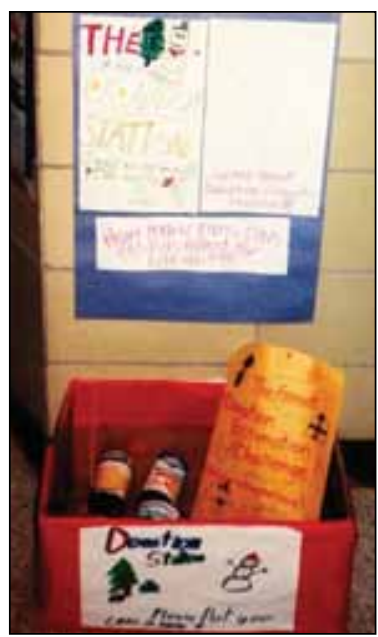




\section{Conclusion}

As educators confront the destructive effects of test-driven pedagogies, the academic literature on creative education has begun to expand. While we honor the innovative work of scholars in this field (e.g., see Craft, 2005), most writers synthesize a variety of theories and concepts, lacking an integrative framework. In contrast, CHACE's foundation in Vygotskian theory offers a solid architecture for the development of novel and imaginative approaches to learning. Further, in drawing on Moll's (1992) "funds of knowledge," CHACE dialectically unites both individual and social understandings of students. After internalizing the shared knowledge of their communities, social individuals bring this expertise into new environments where it is added to, transformed, and re-imagined through dignified, caring interactions. As distillations of the constant activity of humanity, by sharing the awe of socially produced artifacts, we can help children recognize their own never-ceasing inventiveness.

In this paper, we have presented a cultural-historical approach to creative education by emphasizing the obuchenie that exists between teachers who construct stimulating and imaginative learning environments and children who expand each other's creativity through the complementarity evidenced in collaborative efforts, interactions, and explorations. Rather than focusing primarily on the individual, as is the case in most creativity theories, we emphasize the joint creation of innovative projects by agents, peers, and activists as collective learning adventures. We underscore the central role of schooling in the lives of linguistically, economically and culturally diverse children whose education is too frequently oppressive. In contrast, practitioners of CHACE seek ways to highlight and enhance all children's cultural and linguistic funds of knowledge and resilience. In CHACE classrooms, the power of imagination is honored as students are provided with the expressive means to transform their emotions, memories, talents, and lives in relationship with the knowledge, skills, strategies, and dispositions of the curriculum. Joy, intensity, inventiveness, and risk-taking are embraced. Play is validated alongside other diverse semiotic means, broadening children's functional systems as they are modified and expanded throughout the course of development. Finally, we assert that children's creative activities and engagement in their learning provide a hopeful path to their future and all of our futures. 


\section{References}

Anderson, L. W., \& Krathwohl, D. R. et al. (2000). A taxonomy for learning, teaching, and assessing: a revision of Bloom's taxonomy of educational objectives. New York: Allyn \& Bacon.

Cole, M. (1996). Cultural psychology: a once and future discipline. Cambridge, Massachusetts: Harvard University Press.

Connery, M. C. (2011). Profiles in emergent biliteracy: children making meaning in a Chicano community. New York: Peter Lang Publishers.

Connery, M. C., John-Steiner, V., \& MarjanovicShane, A. (2010). Vygotsky and creativity: a cultural-historical approach to play, meaning making, and the arts. New York: Peter Lang Publishers.

Craft. A. (2005). Creativity in schools: tensions and dilemmas. New York: Routledge.

Damasio, A. (1994). Descartes' error: emotion, reason, and the human brain. New York: Penguin Books.

Damasio, A. (2000). The Feeling of what happens: Body and emotion in the making of consciousness. New York: Houghton Mifflin Harcourt.

Damasio, A. (2005). Descartes' error: Emotion, reason, and the human brain. New York: Penguin Books.

Egan, K. (2006). Teaching literacy: Engaging the imagination of new readers and writers. Thousand Oaks, CA: Corwin Press.

Freire, P. (1970). Pedagogy of the oppressed. New York: Herder and Herder.

Gajdamaschko, N. (2005). "Vygotsky on imagination: why an understanding of the imagination is an important issue for schoolteachers", Teaching Education, Volume 15, Issue 1, 13-22.

Gardner, H. (1983). Frames of mind: The theory of multiple intelligences, New York: Basic Books.

Goncu, A. (2012). Discovering self in play. In Robert Lake \& M. Cathrene Connery, Constructing a community of thought: letters on the scholarship, teaching and mentoring of Vera John-Steiner. New York: Peter Lang Publishers, pp. in press.

Holzman, L. (2010). "Without ZPDs, there is no creativity". In M. Cathrene Connery, Vera John-Steiner, \& Ana Marjanovic-Shane. Vygotsky and creativity: a cultural-historical approach to play, meaning making, and the arts (pp. 27-40). New York: Peter Lang Publishers.

John-Steiner, V. (1984). "Learning styles among Pueblo children", Quarterly Newsletter of the Laboratory of Comparative Human Cognition, Volume 6, Number 3, July, 57-62.

John-Steiner, V. (1995). Cognitive pluralism: a sociocultural approach. Mind, Culture, \& Activity, Volume 2, (1), Winter, 2-11.

John-Steiner, V. (2000). Creative collaboration. New York: Oxford University Press.

John-Steiner, V., \& Souberman, E. (1978). Afterward. In Vygotsky, L.S. Mind in society: the development of higher psychological processes (pp. 121-133). Cambridge, MA: Harvard University Press.

John-Steiner et al., (2010). "Dancing with the muses". In M. Cathrene Connery, Vera John-Steiner, \& Ana Marjanovic-Shane. Vygotsky and creativity: a cultural-historical approach to play, meaning making, and the arts (pp. 3-16). New York: Peter Lang Publishers.

Krull, K. (2003). Harvesting hope: the story of Cesar Chavez. New York: Harcourt Children's Books.

Marjanovic-Shane, A. (2010). "From yes and no to me and you." In M. Cathrene Connery, Vera John-Steiner, \& Ana MarjanovicShane. Vygotsky and creativity: a culturalhistorical approach to play, meaning making, and the arts (pp. 41-62). New York: Peter Lang Publishers.

Marjanovic-Shane, A., Connery, M.C., \& JohnSteiner, V. (2010), "A cultural-historical approach to creative education." In M. Cathrene Connery, Vera John-Steiner, 
\& Ana Marjanovic-Shane. Vygotsky and creativity: a cultural-historical approach to play, meaning making, and the arts (pp. 215-232). New York: Peter Lang Publishers.

Miyazaki, K. (2007). Teacher as the imaginative learner: Egan, Saitou and Bakhtin. Paper presented at the 2nd Annual Research Symposium on Imagination and Education. Vancouver, Canada.

Moll, L.C. (1990). Vygotsky and education: Instructional implications and applications of sociohistorical psychology. L.C. Moll (Ed.), New York: Cambridge University Press.

Moll, L.C. (1992). Funds of knowledge for teaching: Using a qualitative approach to connect homes and classrooms. Theory Into Practice, 31(2), 132-141.

Pelaprat, E., \& Cole, M. (2011). "'Minding the Gap': Imagination, Creativity and Human Cognition." Integrative Psychological \& Behavioural Science, 45(4), 397-418.

Rychly, L. (2012). “Dr. Vera John-Steiner as a Key: Unlocking a Theory of Receptive Discourse". In Robert Lake \& M. Cathrene Connery (Eds). Constructing a community of thought: letters on the scholarship, teaching and mentoring of Vera JohnSteiner. New York: Peter Lang Publishers, pp. in press.

Scribner, S. (1997). Thinking in action: Some characteristics of practical thought. In Tobach, E. et al. (Eds.) Mind and social practice: The selected writings of Sylvia Scribner (Chapter 25). New York: Cambridge University Press.

Smagorinsky, P. (2010). "The inscription of self in graphic texts in school". In M. Cathrene Connery, Vera John-Steiner, \& Ana Marjanovic-Shane. Vygotsky and creativity: A cultural-historical approach to play, meaning making, and the arts (pp. 125-140). New York: Peter Lang Publishers.

Smolucha, F. (1992). A reconstruction of Vygotsky's theory of creativity. Creativity Research Journal, 5(1), 49-67.

St. John, P. (2010). "Crossing scripts and swapping riffs." In M. Cathrene Connery, Vera John-Steiner, \& Ana MarjanovicShane. (Eds.) Vygotsky and creativity: a cultural-historical approach to play, meaning making, and the arts (pp. 63-82). New York: Peter Lang Publishers.

Vygotsky, L. S. (1930/2004). Imagination and creativity in childhood. Journal of Russian and Eastern European Psychology, 42(1), 7-97.

Vygotsky, L. S. (1933/1976). Play and its role in the mental development of the child. In J. S. Bruner, A. Jolly, \& K. Sylva (Eds.), PlayIts role in development and evolution (pp. 537-554). New York: Penguin Books Ltd.

Vygotsky, L. S. (1933d/1935). O pedologicheskom analize pedagogicheskogo processa. In L. S. Vygotsky, Umstvennoe razvitie detej $\checkmark$ processe obuchenija. (pp. 116-134). Moscow-Leningrad: Uchpedgiz.

Vygotsky, L. S. (1934/1987). Thinking and speaking: the problem and the approach. Retrieved from www.marxists.org/archive /vygotsky/works/words/lev1.htm.

Vygotsky, L. S. (1934/1987). Thinking and speech: written, inner, and oral speech. Retrieved fromwww.marxists.org/archive/vygotsky /works/words/lev1.htm.

Vygotsky, L. S. (1962). Thought and language. Cambridge, MA: The MIT Press. Published originally in Russian in 1934. Retrieved February 24, 2004 from http://www. marxists.org/archive/vygotsky/works/ words/ Acc

Vygotsky, L. S. (1971). The psychology of art. Cambridge, MA: The MIT Press.

Vygotsky, L.S. (1978). Mind in society: The development of higher psychological processes. London: Harvard University Press.

Vygotsky, L. S. (1981). The problem of the cultural development of the child. In J. V. Wertsch, (Ed.) The concept of activity in Soviet psychology (pp. 144-188). Armonk, NY: Sharpe.

Zoss, M. (2010). "Keeping ideas and language in play." In M. Cathrene Connery, Vera John-Steiner, \& Ana Marjanovic-Shane (Eds.) Vygotsky and creativity: A culturalhistorical approach to play, meaning making, and the arts (pp. 181-198). New York: Peter Lang Publishers. 


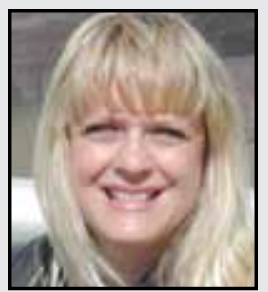

M. Cathrene Connery (B.F.A. \& M.Ed., University of Illinois, Ph.D., University of New Mexico) is Assistant Professor of Education at Ithaca College. A bilingual educator, researcher and advocate, she has presented on theoretical, pedagogic, and programmatic concerns surrounding the education of culturally and linguistically diverse children in the United States and abroad. Her current scholarly interests include fostering the success of refugee students, families, and their community partners. Her books explore cultural-historical approaches to language, learning, and pedagogy, including Profiles in Emergent Biliteracy: Children Making Meaning in a Chicano Community (2011) and Vygotsky and Creativity: A Cultural-historical Approach to Play, Meaning-making, and the Arts (2010) published by Peter Lang.

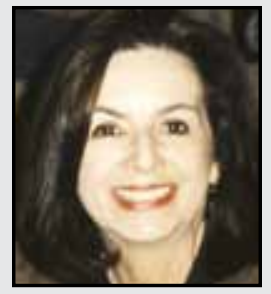

Vera John-Steiner (B.A. Barnard College, Ph.D. University of Chicago). At Yeshiva University and at the University of New Mexico she helped develop interdisciplinary programs in the study of language. After 35 years at UNM, she is currently retired but continues to teach seminars and publishes books and articles. She recently co-edited Vygotsky and Creativity with Connery and Marjanovic-Shane. Her books include Notebooks of the Mind: Explorations on Thinking, winner of the 1990 William James Book Award from the APA and, Creative Collaboration, a topic which has received much scholarly attention since the book's publication. Her most recent book, Loving and Hating Mathematics, is co-authored with the mathematician Reuben Hersh. 